www.jmscr.igmpublication.org

Index Copernicus Value: 79.54

ISSN (e)-2347-176x ISSN (p) 2455-0450

crossref DOI: https://dx.doi.org/10.18535/jmscr/v7i6.154

\title{
A Study on Duchenne Muscular Dystrophy (DMD)
}

\author{
Authors \\ Dr Rahmat Ali MS (Ortho), MC (Spine), Mch (Ortho) ${ }^{1}$, \\ Dr Rajendra Choudhary, MD (Medicine) ${ }^{2 *}$
}

${ }^{1}$ Fellowship in Spine Surgery MIS Spine Surgeon, Associate Prof. \& HOD Deptt. of Ortho Surgery, Govt.

Medical Collage - BASTI (U.P.)

${ }^{2}$ Prof. and Head Deptt. of Medicine, Govt. Medical College Basti (UP)

*Corresponding Author

Dr Rajendra Choudhary, MD (Medicine)

Prof. and Head Deptt. Of Medicine, Govt. Medical college Basti (UP), India

\begin{abstract}
Duchenne muscular dystrophy or Psendo Hypertroplnic Muscular Dystrophy is heterogenous group of inherited disorder $C$ graddal degeneration of muscle fibres. It is Inheritance sex linked disease and boys are sufferer while girls are carrier. Patient dies in $2^{\text {nd }} 13^{\text {rd }}$ decade of life due to pulmoray infection and cardionyopahy.

Keywords: X linked disease, mutation, Grower's Sing, Baker Muscular dystrophy, serum creatine kinase, EMG, muscle Biopsy.
\end{abstract}

\section{Introduction}

Duchenne Muscular Dystrophy (DMD) is X-linked inheritance disease, boys are sufferer while girls are carrier. Perintal history is normal. Early development of child is normal or delayed when child starts walking in $2^{\text {nd }}$ years gait is usually slight abnormal hypertrophy of calf cusele may develop at age of $3^{\text {rd }}$ years but patient may not notice till age of 4 to 5 years. Toddler has difficulty in climbing stairs. He takes of support of railing and wall. Distribution of atrophic/hypertrophic are characteristic muscles.

Calf muscle, glutie, pectoral, braclio radialis and tongue are large. All muscles get atrophy and child becomes bed ridden. Kyphoscoliosis is other complication of disease. Diagnosis is suspect especially if there is family history of myopathy.

\section{Incidence}

Most common muscular dystrophy is duchenne muscular dystrophy (DMD) is $\mathrm{X}$ - linked recessive disorder. It occers in 2 to 3 boys per 10,000 boys. It is due to mutation in hyertrophin gene. The Gene is expressed in all muscles and brain. This causes loss of muscle cells and progressive proximal to distal muscle weakness. Despite advance in medical management it continues to be fatal in $2^{\text {nd }}$ and $3^{\text {rd }}$ decace of life.

Backer-Muscluar Dystrophy (BMD) results from less extensive citations in the same gene and produces a partially furctional dystrophin protein. Clinically disease is less severe with a later onset and less profound weakness. 


\section{Diagnosis}

\section{Serum Creatine Phospho Kinase (CPK):}

Are elevated in most boy patient as well as in carrier females which is 200/300 times more than normal value even before clinical, manitestations becomes obvious and help in genetic councelling.

\section{Electromyogram (EMG):}

Shows- decreased amplitude and duration of motor unit potential.

\section{Electro Cardiogram (ECG):}

Shoows Arrythmia.

\section{Histopathalogy of muscle fibres:}

Shows diffuse changes of degeneration, variation in size and central nuclei of muscle fibres. Muscle atrophy secondary to neurological disease shows bundles of muscle fibres in the degeneration interspersed with bundles of normal muscele fibres

\section{Prognosis}

By the age of 12 Years Ambulation caeses and by the age of $2^{\text {nd }} / 3^{\text {rd }}$ decade ptdies due to recurrent chest infection and heart failure due to associated cardiomyopathy.

\section{Factor-Prolonging Muscles weakness}

Prolonged immobilization like plaster caste after hastens weakness of muscles.

\section{Management}

There is no definite and effective treatment.

Prolong Immobilization should be avoided.

Physiotherapy/Exercise to be done.

Kyphoscoliosis to be prevented by using tight brdces.

Respiratory complication showed be prevented by vigorous antibiotic therapy.

Cardioryopathy and congestive cardiae failure are managed by conventional approaches.

Emotional support to be given to patient and family.

Progrosis should be explained.

Crticosteroid is main drug of D.M.D.

Gene therapy

\section{Differential Diagnosis}

1. Myelopathies

In myelopathies, sensory changes and distribution of weakness is variable. Deep tendon reflexes are generally brisk. Abdominal are often absent. EMG shows neurogenic pattern, peripheral N. Conduction delayed in late stage. Muscle-Biopsy shows neurogenic type of atrophy. CSF protene may be elevated, muscle enzymes like, CPK, Aldolase and SGOT are within normal limit.

\section{Polyneuritis}

Sensory changes are usually present. There may be paralgesia or hyperalgesia. Distribution of weakness is distal and symmetrical except in case of Infective $\underline{\text { Polyneuritis (in which proximal weakness }}$ may be there):-

- Tendon reflexes are absent.

- Abdominal reflexes are present.

- Sphincters are usually not involved.

- EMG and muscle Biopsy are of Neurogenic type.

- CSF proteins is elevated in gullain Barre syndrome.

- Muscle enzymes are normal.

\section{Backer Type}

It is $\mathrm{X}$ linked inheritance, age of onset between 5 and 25 years. Becker muscular dystrophy result from less extensive mutations in same gen and produces a partially functional dystrophin protein. Clinical disease less sever with later onset and less profound weakness.

\section{Fascio scapulo-Humoral}

Both sexes in several generations are affected. Age of onset around puberty.

5. Limba girdle (Erbtype)

Autosomal recessive inheritance. Age of onset is around 10 years.

\section{Congenital myopathies:}

Rare inherited dis-order. 


\section{Case History}

Patient about 12 years male resident of Distt. - Basti came to Govt. Medical College Basti in ortho OPD. Patient came in our OPD walking with support and his gate was waddling gait. Patient was examined and his calf muscles were enlarged in size $\mathrm{B} / \mathrm{L}$. Local temperature was normal, skin/muscle was non tender and soft to firm. His spine was normal. On standing from ground he used his both hands on both knees to take support. Patient having one sister who is 6 years old. She is normal in each aspect. Patient had normal delivery at hospital without any problem/complication. Patient having no history of fever. His serum creative kniase is 7111. EMG showed decreased amplitude. Histopathology could not be done as corsent was not given by his parents. Patient has one sister 6 years old without any problem her serum creatine kinase was 3212. Her gait was normal.
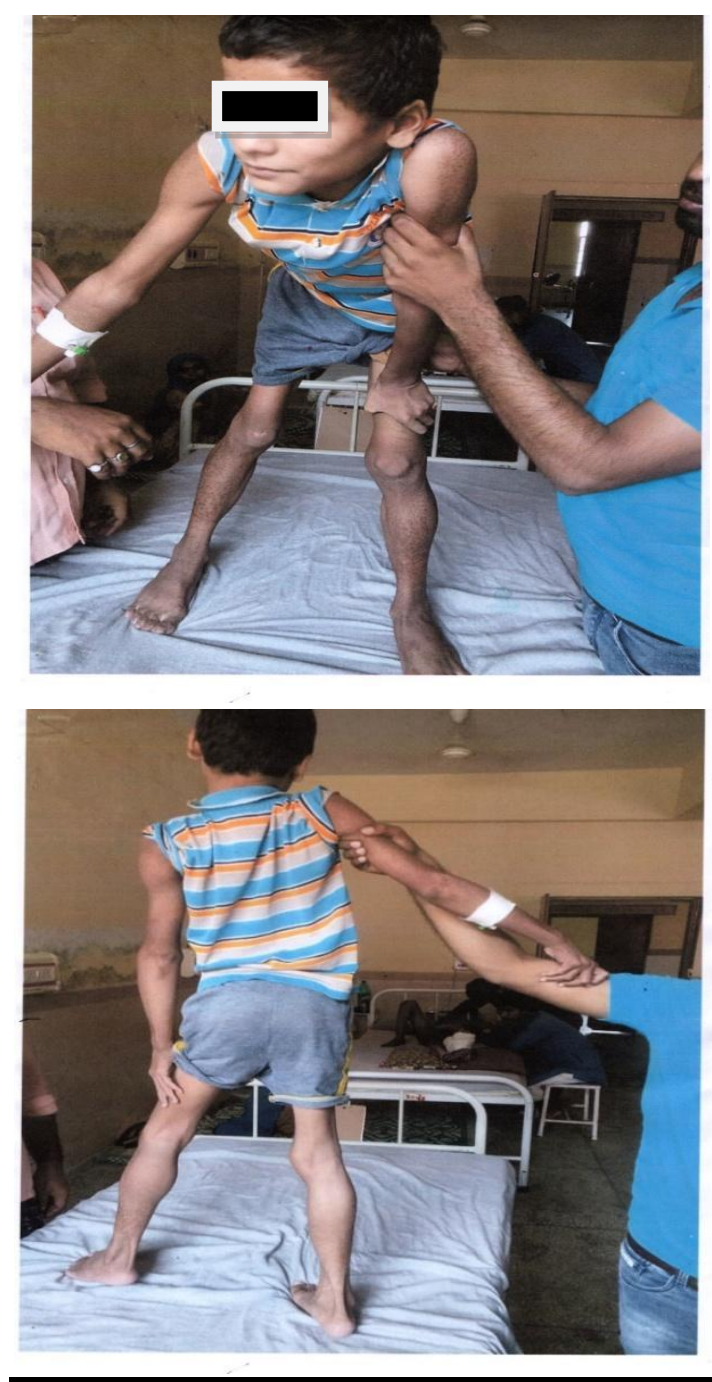

Analysis

Patient was 12 years boy and diagnoed as DMD/Muscular Hypertrophy. He was unable to stand self but can with support and had waddling gait. His both calf muscle was abnormally enlarged without other finding. Spine was normal. SCPK was rised to 300 times more than normal. Patient had one sister 6 years old without any problem though her SCPK was also raised in same proportion as brother (patient). EMG also showed abnormal changes. Histopathalogy of calf muscle also important diagnostic parameter in this case. But parents refused to due to injury/trama during biopsy procedure. Progress of disease was explained to the parents of patient as at the age of 20-30 years. Life can be fatel due to chest infection and heart failure due to cardiomyopathy. DMD boys are sufferer and girls are carries.

This disease is X-linked disease and boys are suffers while girls are carrier. Diagnosis and investigation are mandatory. physical exercise and corticosteroids are main therapy of DMD patients.

\section{Conclusion}

Ducinne Muscular Dystrophy is X-linked inheritance disease, boys are suffers while girls are carrier, Though this disease appear at the age of 20-30 years. Patient dies due to chest infection and heart failure due to cardiomyopathy. Psysiotherapy corticosteroid and reassurance are main treatment.

\section{References}

1. Abbs, S. and Bobrow, M. (1992). Analysis of quantitative PCR for the diagnosis of deletion and duplication carriers in the dystrophin gene. J. Med. Genet. 29:191-196.

2. Abbs, S., Yau, S.C., Mathew, C.G., and Bobrow, M. (1991). A convenient multiplex PCR system for the detection of dystrophin gene deletions: a comparative analysis with cDNA hybridisation shows mistypings by both methods. J. Med. Genet. 28:304-311.

3. Ad Hoc Committee on Mutation Nomenclature (1996). Update on 
nomenclature for human gene mutations. Hum. Mutat. 8:197-202.

4. Ahn, A.H. and Kunkel, L.M. (1995). Syntrophin binds to an alternatively spliced exon of dystrophin. J. Cell Biol. 128:363-371.

5. Ambrose, H.J., Blake, D.J., Nawrotzki, R.A., and Davies, K.E. (1996). Genomic organization of the mouse dystrobrevin gene: alternative splicing generates multiple dystrobrevin isoforms from a single gene on chromosome 18. Am. J. Hum. Genet. 59, A145(Abstract)">

6. Arahata, K., Hoffman, E.P., Kunkel, L.M., Ishiura, S., Tsukahara, T., Ishihara, T., Sunohara, T., Nonaka, I., Ozawa, E., and Sugita, H. (1989). Dystrophin diagnosis: comparison of dystrophin abnormalities by immunofluorescent and immunoblot analyses. Proc. natl. Acad. Sci. USA 86:7154-7158.

7. Austin, R.C., Howard, P.L., D'Souza, V.N., Klamut, H.J., and Ray, P.N. (1995). Cloning and characterization of alternatively spliced isoforms of Dp71. Hum. Mol. Genet. 4:14751483.

8. Bakker, E., Hofker, M.H., Goor, N., Mandel, J.L., Wrogemann, K., Davies, K.E., Kunkel, L., Willard, H.F., Fenton, W.A., Sandkuyl, L., Majoor-Krakauer, D., Van Essen, A.J., Jahoda, M.G.J., Sachs, E., Van Ommen, G.J.B., and Pearson, P.L. (1985). Prenatal diagnosis and carrier detection of Duchenne Muscular Dystrophy with closely linked RFLPs. Lancet i:655-658.

9. Bar, S., Barnea, E., Levy, Z., Neuman, S., Yaffe, D., and Nudel, U. (1990). A novel product of the Duchenne muscular dystrophy gene which greatly differs from the known isoforms in structure and tissue distribution. Biochem. J. 272:557-560.

10. Barbieri, A.M., Soriani, N., Ferlini, A., Michelato, A., Ferrari, M., and Carrera, P. (1996). Seven novel additional small mutations and a new alternative splicing in the human dystrophin gene detected by heteroduplex analysis and restricted RT-PCR heteroduplex analysis of illegitimate transcripts. Eur. J. Hum. Genet. 4:183-187.

11. Bartolo, C., Papp, A.C., Snyder, P.J., Sedra, M.S., Burghes, A.H.M., Hall, C.D., Mendell, J.R., and Prior, T.W. (1996). A novel splice site mutation in a becker muscular dystrophy patient. J Med Genet 33:324-327.

12. Baumbach, L.A., Chamberlain, J.S., Ward, P.A., Farwell, N.J., and Caskey, C.T. (1989). Molecular and clinical correlations of deletions leading to Duchenne and Becker muscular dystrophies. Neurol. 465-474.

13. Beggs, A.H. (1994). Multiplex PCR for identifying dystrophin gene deletions. In: Current protocols in Human Genetics. Anonymouspp. 9.3.1-9.3.17.

14. Bentley-Lawrence, J., Singer, R.H., and McNeil, J.A. (1991). Interphase and metaphase resolution of different distances within the human dystrophin gene. Science 249:928-932

15. Beutler, E., McKusick, V.A., Motulsky, A.G., Scriver, C.R., and Hutchinson, F. (1996). Mutation nomenclature: nicknames, systematic names and, unique identifiers. Hum. Mutat. 8:203-206.

16. Blonden, L.A.J., Terwindt, G.M., Den Dunnen, J.T., and Van Ommen, G.J.B. (1994). A polymorphic STS in intron 44 of the dystrophin gene. Hum. Genet. 93:479480.

17. Bonilla, E., Samitt, C.E., Miranda, A.F., Hays, A.P., Salviati, G., Dimauro, S., Kunkel, L.M., Hoffman, E.P., and Rowland, L.P. (1988). Duchenne muscular dystrophy: Deficiency of dystrophin at the muscle cell surface. Cell 54:447-452.

18. Bonilla, E., Schmidt, B., Samitt, C.E., Miranda, A.F., Hays, A.P., de Oliveira, A.B.S., Chang, H.W., Servidei, S., Ricci, E., Younger, D.S., and Dimauro, S. (1988). Normal and dystrophin-deficient muscle fibers in carriers of the gene for 
Duchenne muscular dystrophy. Am. J. Pathol 133:440-445.

19. Bonnemann, C.G., Passos-Bueno, M.R., McNally, E.M., Vainzof, M., Moreira, E.S., Noguchi, S., Ozawa, E., Zatz, M., and Kunkel, L.M. (1996). Genomic screening for beta-sarcoglycan gene mutations: missense mutations may cuase severe lin\mg-girdle muscular dystrophy tyep 2E (LGMD 2E). Hum. Mol. Genet. 5:1953-1961.

20. Boyd, Y. and Buckle, V.J. (1986). Cytogenetic heterogeneity of translocations associated with Duchenne muscular dystrophy. Clin. Genet. 29:108-115. 